\title{
DISCOURSES AND DEPICTIONS OF HOLOCAUST EDUCATION IN LITHUANIAN HISTORY TEXTBOOKS (1992-2012)
}

\author{
AKVILĖ NAUDŽIŪNIENĖ \\ Faculty of History, Vilnius University, \\ Universiteto g. 7, Vilnius, Lithuania

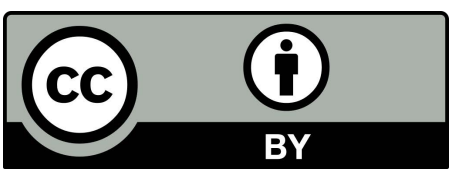 \\ E-mail address: akvile.naudziuniene@gmail.com
}

\begin{abstract}
The topic of the Holocaust is a relatively new issue in Lithuanian historical education - only with the regained independence from the Soviet Union in 1990 did Lithuanians have a chance to include the Holocaust theme into the main school curriculum. Of course, its development through the first two decades has not been steady and even - in the beginning of the creation of the new educational system the Holocaust did not receive so much attention as in later years with the relation to integration with the European Union (2004) and development of historical studies on the Holocaust within the Lithuanian academic community. This article aims to analyse the representation of the Holocaust in Lithuanian educational system during the first two decades after Lithuania regained its independence. So the main basis of empirical data will be all history textbooks for Lithuanian school education (from the 5th grade to the last, 12th grade) published in the period of 1992-2012, and educational programmes presented by the State's Ministry of Education and Science. In order to objectively evaluate the Lithuanian situation regarding Holocaust education the article will discuss and compare the main trends of Holocaust education development in neighbouring countries, which also suffered from Holocaust and could not freely speak about the issue during the Communist regime.
\end{abstract}

Key words: Holocaust, education, ethnic minorities, post-Soviet countries, textbooks

\section{INTRODUCTION: \\ THE CONTEXT OF HOLOCAUST EDUCATION IN LITHUANIA}

The academic study of the Holocaust as a historical event is a controversial task, thus the topic of Holocaust education in schools is even more a subject of different clashing opinions, because it includes one more influential and essential element - society as a whole, not just scholars, who are interested to present the best version of the so-called historical truth (or academic interpretation of history to call it what it is). Actually, it is quite paradoxical, but the academic community does not usually have much to do with historical education at school at all. Of course, research of scholars about the Holocaust should 
be the basis of knowledge for textbook authors and teachers in the classrooms, but due to the oversimplifying nature of textbooks or the short time for the representation of the Holocaust during a forty-five minutes lesson, they tend to choose one position regarding the Holocaust presented in academic circles, thus to show one interpretation, to pay attention to the linear story.

The Holocaust topic is a relatively new issue in Lithuanian historical education - only with the regained independence from the Soviet Union in 1990, Lithuanians had a chance (or even an obligation) to include the Holocaust theme into the main school curriculum. This difficult situation is a co-product of Soviet ideology, which ignored the Holocaust as a tragedy of the Jewish nation and tried to establish the understanding of it as an evil act of Germans against all the nations with no exceptions (Lietuvos žydai, 2012). Also the fact, that a part of Lithuanian population during the Second World War had collaborated with the Nazis, was influential in the process of ignoring the Holocaust topic over the years. A collective guilt of a nation is never an easy issue, especially for the nation, which fought for regaining its independence and creating a patriotic national narrative for Lithuanians to be proud of their heritage. Of course, development of Holocaust education in the independent Lithuania through the first two decades has not been steady and even - in the beginning of the creation of new educational system the Holocaust did not receive so much attention as in later years with relation to integration into the European Union (2004) and development of historical studies on the Holocaust within the Lithuanian academic community as well as an open access to the studies presented by Western historians.

This article aims to analyse the representation of Holocaust history in the Lithuanian educational system at the school level during the first two decades after Lithuanian independence. It will present a constructive analysis of textbooks' (1992-2012) contents, forms, style, interpretations, contexts etc. regarding the Holocaust topic. In order to evaluate Lithuanian situation regarding Holocaust education the main objectives of this article are: 1) to discuss the main trends of Holocaust education development in Lithuania; 2) to compare Holocaust education in Lithuania with such practices in neighbouring countries, which also have a history closely linked with the Holocaust and could not freely speak about the issue during the Communist regime; 3) to evaluate the progress of historical understanding presented in the textbooks and progress made in Holocaust education in Lithuania in general during the first two decades after Lithuanian independence from USSR.

The main sources of information used in this paper are Lithuanian history schoolbooks and educational programmes for history for all Lithuanian schools. During this research 40 history textbooks (for the $8^{\text {th }}-12^{\text {th }}$ grades, see Table 1) published after Lithuanian independence and approved by the Lithuanian Ministry of Education and Science ${ }^{11}$ have been analysed. In accordance with the chronologically concentrated content proposed by the Ministry of Education and Science for world and Lithuanian history for school education

11 Alistoftextbooksapprovedforthe2011-2012schoolyears(2012). RetrievedJanuary13,2017fromhttp:/ / www.sac.smm.lt/mokymosi-istekliai/vadoveliai/bendrojo-ugdymo-dalyku-vadoveliai/. 
(Skirius, 2009), not whole school-year textbooks where chosen from current history textbooks. Textbooks designed for the $5^{\text {th }}-7^{\text {th }}$ grades were not included in the main analysis because their history course is concentrated either only on ancient history up to the middle ages (for the $7^{\text {th }}$ ) (Socialinis ugdymas..., 2011) or Lithuanian and world history is reviewed on a very large scale, without going into detail - students are introduced to an abstract image of a certain period (for the $5^{\text {th }}-7^{\text {th }}$ grades) (Bendrojo lavinimo mokyklos programos..., 1997). Due to the fact that these courses are only introductory it is not surprising that topics representing Lithuanian ethnic minorities (which are not very popular even in higher grades) are not included in them.

Attention towards the Holocaust education, while highlighting its main weaknesses and main strong points, is significant not only because the Holocaust topic is widely understood as "a critical catalyst in the further development of teaching and learning about human rights" (Nasson, 2013), but also because textbooks and their depictions of the Holocaust represent the way society understands itself and tries to establish this understanding in a sphere of historical culture. In spite of the nationalist element, which is common to history textbooks all over the world, introduction of the Holocaust theme puts textbook authors in the position of narrators of global history. At this point national and transnational narratives interlink creating a different representation of the Holocaust based on a certain country and its historical consciousness.

\section{THE HOLOCAUST TOPIC WITHIN THE FRAMEWORK OF SOCIAL EDUCATION PROGRAMMES FOR SCHOOLS}

In the programmes for social education at Lithuanian schools (which include history) for the first two decades of Lithuanian independence there were no specific indications regarding the topic of ethnic minorities ${ }^{12}$. On the one hand, it can be seen as an opportunity and a liberty given for the textbook authors to explore this topic in many ways. However, on the other hand, while there is no indication regarding the fact, if ethnic minorities and their history must be mentioned in the school curricula, there is a big chance, that they will be simply left out as an unnecessary element (i.e. in this case "unnecessary" means not required officially). A sole exception to this rule is the topic of the Holocaust. However, in social programs, which can be as well called as requirements for textbook authors and teachers, the Holocaust is presented as an historical event unrelated with the history of any particular ethnic group of Lithuania

12 It is important to notice, that the newest programme for social education in schools (which includes history presents the topic of ethnic minorities in Lithuania as a separate and significant issue to discuss in the classroom. Retrieved February 1, 2017 from http:/ / www.smm.lt/web/ lt/pedagogams/ugdymas/ugdymo_planai_1. This formal recognition encourages teachers to incorporate the history and culture of local ethnic minorities in their curriculum. However, due to the scope of this research (1992-2012) the new programme is not being analysed in this article. Also, as this programme is just in progress for two years it is impossible to evaluate its implications on history textbooks. 
(„,To evaluate crimes executed by Nazis and Soviets during the Second World War in Lithuania, including the Holocaust" (Socialinis ugdymas..., 2011, p. 37), such notion as "Jew" is not even mentioned. Thus it has not changed much from the Soviet point of view regarding crimes of the Second World War - it has only put Soviet officials in the position of criminals as well. However, the ignorance of such sensitive issue is caused not only by the Soviet ideology relicts, it is also supported by nationalistic approach to Lithuania`s history, which seeks to present Lithuanians as the main victims of the Second World War in the Eastern front. It goes even far beyond the tendencies of the Western education, where the Holocaust is presented as a genocide of only one ethnic group - Jews (excluding Roma), or Jews are presented as a separate race (Lindquist, 2006). Unfortunately, adequate situation has been noticed in other East European countries. Local researchers, who analysed representation of Jewish history in the school curriculum in Poland (Wegrzynek, 1998), Czech Republic (Pawlat, 1995), Slovakia (Salner, \& Salnerova, 1999), Hungary (Kovacs, 2000) and Russia (Krichevsky, 2001) unambiguously emphasize the same tendencies of educational programmes as noticed in Lithuania - the attention paid to the Holocaust overwhelms the attention given to topics of Jewish history, which is told sporadically, with oversimplifications or even ignored. Hanna Węgrzynek argues, that in spite of historical multiculturalism tradition in Poland, the contribution of ethnic minorities to Poland's history is often eliminated from the history textbooks. Fragmentary representation of ethnic minorities is followed with mistakes in facts, which are not rare in the wider analysis of the Holocaust topic (Węgrzynek, 1998). The Polish historian is seconded by the opinion of Lithuanian historian Jurgita Verbickienè, who states that, "existing and suggested popular ideas of Lithuanian Jerusalem commemoration are the same as educational programs for schools, which consistently explains to the children, how and who killed the Jews, but fail to mention who those Jews are - religiously, culturally, and what is their contribution to Lithuanian culture etc" (Šiaučiūnaitè-Verbickienè, 2009, p. 228). It is worth noting, that constantly connected representation of Polish and Lithuanian history faces the common paradoxical problem - schoolchildren learn about the vast numbers of Jews killed in Poland and Lithuania during the Second World War without even an introduction about vast Jewish communities, which lived there before. This unfortunate situation is well illustrated by the Lithuanian textbooks for the $5^{\text {th }}$ grade (the beginning of the middle school) (Laužikas, 2008) - children, who, according to the general educational programmes for primary schools (General programs for primary and middle-school education), did not have a possibility to achieve certain knowledge about ethnic minorities in Lithuania, begin their learning process with the facts, how those ethnic groups were exterminated. Although history textbooks for the fifth grade are not a main source for research presented in this article, it is worth paying attention to more general object relevant in this context - teaching about the Holocaust as early as in the fifth grade, which is questioned not only because of previously mentioned inadequacy, but because of the appropriateness to present such a cruel and complex topic to such an 
early stage of childhood. In this case this kind of topic should be accompanied by the psychologically well considered presentation, which should be interconnected with wider contextual knowledge (Krieg, 2015).

As can be seen from the presented analysis done in Eastern and Middle Europe, political ideology is inevitable in the development of textbooks. After the collapse of Communism some new political parties in Hungary lost their legitimacy and continuity and were trying to justify their ideologies as continuing from political and intellectual life in interwar Hungary. Thus, the Holocaust was relativized as a tragedy not only for Jews - people of other ethnic origins also died. A lack of consensus caused by this perspective in the first post-Communist schoolbooks is still visible in Hungary (Kovacs, 2000). During the last few years Hungary has caught the eye of the world press for its strong anti-Semitic and xenophobic moods in public life ${ }^{13}$, which show both holes in education and correlation of history didactics and public mentality. An adequate situation can be seen in Slovakia where strong Slovak ethnocentrism and incapability of understanding their society as pluralist causes one-sided representation (which is only focused on the Slovak nation) in their schoolbooks (Salner, \& Salnerova, 1999). Although in literal sense the Lithuanian state is also a powerful influence for the introduction of historical narratives into the school textbooks, the situation regarding Lithuanian history textbooks seems more promising that in Hungary or Slovakia - despite the fact that the history narrative can be hard to reach for ethnic minorities, the majority of politicians in charge of the educational system do not represent negative position, that would restrict education, which encourages perceiving of Lithuanian historical multiculturalism.

In Lithuanian programmes for social education in schools the understanding of major historical events while placing adequate examples from local history is encouraged, it especially highlights the possibility to visit places of Holocaust memorials in the certain school district (Socialinis ugdymas..., 2011). Naturally, the aim to incorporate local aspects into historical education is very complicated, however, this concentration only on the Holocaust memorials, presupposes quite limited historical understanding - it shows only the most tragic part of Jewish history in Lithuania, excluding all the other messages, which could be presented to schoolchildren via representation of multicultural history of their homeland. Instead, there is a lack of attention towards still existing (and sometimes even still in use) cultural heritage of ethnic minorities. The historical understanding influenced by the experience of still existing heritage (not only the one, which is lost) is more likely to reflect the connection between past and present. Also, it is important to note, that this kind of encouragement is only on formal paper - textbooks are oriented towards the presentation of Lithuanian history as a whole, different regional narratives are not presented. Thus the presentation of local Holocaust memorials is left to the personal initiatives of history teachers.

13 For example, See. Hungary anti-Semitism: MP condemned over "list of Jews" (2012). Retrieved January 16, 2017 from http://www.bbc.co.uk/news/world-europe-20510648 or Anti-Semitism in Hungary: Marton's list (2012). Retrieved January 16, 2017 from http:/ / www.economist. com/blogs/easternapproaches/2012/11/anti-semitism-hungary. 


\section{THE HOLOCAUST AND ITS REPRESENTATION IN LITHUANIAN HISTORY TEXTBOOKS}

It is worth noting, that in spite of different narration style in all history textbooks, analysed during this research, the main topics, which represented details of ethnic minorities' history and heritage in Lithuania, correlate. It is possible to distinguish 5 of them:

1. Society of the Grand Duchy of Lithuania in the $16^{\text {th }}-17^{\text {th }}$ centuries. Usually it includes short presentations of main ethnic or religious minorities: Jews, Karaites, Tatars - especially their religious beliefs, cultural differences, percentage in the whole population etc.

2. Social status of Lithuanian inhabitants at the end of $19^{\text {th }}$ century. In the framework of this topic a specific situation of ethnic minorities in the Western part of the Russian Empire is introduced.

3. The Lithuanian Republic during the interwar period (1918-1939). Although, while presenting the cultural background of Lithuania during the interwar period there is no mentioning of any Jewish artists or scientists, three of them are indicated in the chapter dedicated to Holocaust representation - chemist, winner of Nobel price Aaron Klug, genius violinist Jascha Heifetz and a worldwide known sculptor Jacques Lipchitz (Kapleris, 2007). This kind of acknowledgment of interwar artists and scientists only in the context of the Holocaust event seems artificial and forced - as if their talents had shown through only in the darkness of the Holocaust tragedy and as if it was not so extraordinary in the context of interwar Lithuania.

4. Vilnius district during the interwar period (1920-1939). This topic includes Lithuanian-Polish relations and narration about their both physical and moral battle over the Vilnius and its district.

5. The Holocaust in Lithuania.

The topic of the Holocaust in Lithuania can be considered as an exceptional one in the context of ethnic minorities' representation in the textbooks - sometimes it has its own subchapter (in 2 out of 11 textbooks) and sometimes it has at least a smaller subchapter next to the chapter on Nazi occupation in Lithuania during the Second World War (8 out of 11 textbooks), and in only one textbook, which is also chronologically suitable for Holocaust representation, this topic is missing. Of course, the topic of the Holocaust is related not with all Lithuanian ethnic minorities, but mostly Jews and their tragedy in Lithuania (although, in rare cases Roma as victims of the same genocide are mentioned as well - in 4 out of 11 textbooks), so it is common for analysed textbook authors to try to explain the relationship between Jews and Lithuanians of that time, searching for guilty and not so guilty ones, trying to justify or to moralize. As an influential factor, which defined Jewish-Lithuanian relationship before the events of the Holocaust took place, was the first Soviet occupation in Lithuania, which is often related with Jewish collaboration and thus it is explained 
as the main point of conflict, which led to hatred towards Jews during the later Nazi occupation. Although this fact is placed in all the textbooks, which talk about the Holocaust, only one of their authors decides to express his own opinion about this matter: „But it cannot justify that part of Lithuanians, who later participated in the mass murders of Jews organized by Nazi occupants. The Soviet occupation was hard on all of the Lithuanian population, including Jews as well" (Bakonis, 2009, p. 82). This recognition is highly significant, because in spite the fact that many history textbooks recognize the fact, that Lithuanians participated in the horror of the Holocaust, they are not ready to face this fact without trying to place the guilt to other higher forces - Nazis, Soviets or mental illnesses etc. However, many researchers of Holocaust education over the world agree, that it is even more important to explore and contest the role of so-called "bystanders" (the ones, who did not cooperate with Nazis, but did not make an effort to save Jews either) (Nasson, 2013). This difficult aspect stays untouched in Lithuanian history textbooks, while the most attention is paid to explain the actions of those, who cooperated with Nazis and were active participants of Jewish mass murders. The most common presentation of such people introduces them as criminals (Tamošaitis, 2010) or as fanatics, lowlifes, who were forced to do so (Gečas, 2001). This kind of representation could be understood as an attempt to vindicate Lithuanians as a nation from the crimes of the Holocaust, placing marginalised members of society as scapegoats. This position is quite similar to the one chosen by the Soviet historians, who had to consider all victims of the war as "Soviet citizens" without any ethnic identification, so the distinction between different ethnic groups and their place in the eventsof Holocaust has been blurred or ignored (Dietsch, 2012). Thus, from both of these points of view it is very easy to label the Holocaust as a general mass murder of civilians during the war.

A wider representation of the Holocaust topic is also related to the double conception of textbooks (when Lithuanian and World history are presented in parallel) - there are separate chapters on Nazi Germany in the interwar period, and its anti-Semitic politics. Textbook authors tend to emphasize, that the guilt for the Holocaust tragedy both in the whole Europe and in Lithuania should be taken by Nazi Germany. The exclusive representation of the Holocaust topic is determined not only by the moral load it holds, but also by the aim of the textbook authors to search for reasons and explanations, not only to state facts without questioning them. This versatile attitude towards the Holocaust is common for the textbooks oriented towards the last years of education in gymnasiums.

In the "Guidelines for Teaching the Holocaust: Avoiding Common Pedagogical Errors" David H. Lindquist emphasized that personal experiences are highly important in the Holocaust education in order to make a connection not only with the facts of this event, but with its reality as well (Lindquist, 2006 , p. 215). This problem is common to Lithuanian history textbooks as well - only two analysed textbooks have introduced their readers to the personal stories of Holocaust survivors. One of them presented "The story of Jewish 
girl Mirjam" (Bakonis, 2009, p. 73) and another one - "The recollections about the events of 1940-1941 and its influence to her family written by Jewish teenager from Kaunas" (Kasperavičius, 2001, p. 116). Both of these stories not only supplement the main narrative about the Holocaust provided by the textbook authors, but they also reveal even more characteristic aspects of the period. The presentation of details from personal life, especially from the position of teenagers to teenagers could help to avoid the danger of schoolchildren seeing the Holocaust as an ordinary historical event, which needs to be studied.

Although, in the Lithuanian history textbooks the Holocaust as a historical event is presented quite widely in the matters of dates, numbers, and places and has a consistent narrative, they lack both - the presentation of preHolocaust conditions and its effects on the life in Lithuania after the Second World War. Although, it seems only logical, that as the historical framework for study of the Holocaust the history of anti-Semitism in the region should be presented as well, textbooks either tend to ignore the topic of anti-Semitism until it is already involved in the topic of the Holocaust, or take an extremely naive approach and seek to follow nowadays popular ideas of Lithuania as a multicultural and very tolerant state in early modern ages - so they talk about anti-Semitism as a shadow over the Western Europe, which was not an issue in the lands of the Grand Duchy of Lithuania. There are even such statements as "there are not known incidents of religious anti-Semitism" in the GDL during the Middle Ages (Bilieriūtè, \& Litvinaitè, 2008, p. 154) or topic about anti-Semitism included only the context of Western Europe, Lithuanian situation is not even mentioned (Butvilaite, 2010). The narrative of ideal living conditions of Jews in the Grand Duchy of Lithuania presented in school textbooks does not correspond with academically presented historical knowledge (Lietuvos žydai, 2012). The similar situation is seen in the short fragmentary mentioning of anti-Semitism during the interwar period in Lithuania - existence of anti-Semitism as such is recognized, but it is presented as only a small and unimportant detail of everyday life. For example, stating that "During the interwar period the government was fast to stop any actions of anti-Semitism and its perpetrators were soon disciplined" (Tamošaitis, 2010, p. 112), while it does not explain why such anti-Semitic actions arose. This lack of information about anti-Semitism in history textbooks can be seen from two different perspectives. Firstly, it might be that textbook authors themselves are not closely familiar with this topic - it might seem unacceptable, however, there are several examples of textbooks presenting several centuries being written only by one or two authors. And secondly, as an issue of anti-Semitism and its history has not been highlighted as an important topic in the State's educational programmes, thus students are not required to be familiar with it during their exams, textbook authors simply ignore it and emphasize topics which are understood as useful in the final tests. In this context of anti-Semitism representation (or, actually, its absence) students have to start learning about the Holocaust without any understanding about its possible preconditions, which can easily lead to the misinterpretation of 
Jewish-Lithuanian relations, connection between Nazi occupation and Holocaust or connection between Nazi occupation and Lithuanians involved in Jewish mass murders.

Generally, history textbooks represent the situation of ethnic minorities and their heritage in Lithuania after the Second World War until nowadays very poorly. It is quite paradoxical, considering the fact, that programmes of general education constantly highlight the idea, that understanding of recent events, making connections with today's processes and historical events are main priorities and goals of history education at school level (Socialinis ugdymas..., 2011). In the textbooks themselves we could distinguish only humble summaries about the situation of ethnic minorities in Lithuania after the Second World War, they remind us of small fragments from newspapers: „During the war Vilnius lost its old inhabitants. Nazis destroyed a huge Jewish community. After the war about one thousand people immigrated to Poland $-80 \%$ of the at that time city population. <... Ethnic constitution of city inhabitants has crucially changed..." (Kapleris, 2007, p. 203). It is actually not surprising, because the educational programme for teaching modern Lithuanian history (period of 1918-1990) (Jakubčionis, \& Kaubrys, 2006), which was prepared in 2006, did not even mention the representation of Lithuanian ethnic minorities and their experiences during the Soviet regime, and suggestions for topics related with ethnic minorities end at the point of Jewish genocide in Lithuania during the Second World War (Jakubčionis, \& Kaubrys, 2006).

A way to narrate history through illustrations (photographs, iconography etc.), which is aesthetically appealing and calling for the attention, is also used in the textbooks for the presentation of ethnic minorities and especially their heritage (sacral buildings, living space, ethnic clothes, main historical events). In the thirty five textbooks used for this study there are 60 illustrations on the topic of ethnic minorities (their number in each textbook is quite different, it should be noted, that there are some textbooks, which do not have any illustrations related to this topic at all). Illustrations are used as an additional means to strengthen the suggestibility of the narrated story, which is often the case in Holocaust representation. The number of illustrations in reference to Holocaust events are even higher that the general number of illustrations presenting all ethnic minorities - in 35 analysed history textbooks there are 22 illustrations of Holocaust history, while there are only 2 illustrations of Polish ethnic group, 6 of Karaites, 8 of Tatars and 21 of Jews (not related with the Holocaust). As the most common images, depicted for illustration of this tragic period, are photographs from the daily life in Vilnius and Kaunas ghettos, a photograph of mass murder in "Lietūkis" garage and also portraits of those, who saved Jews from all this massacre (Lithuanian librarian Ona Šimaite and Japanese consul Chiune Sugihara). However, it is still quite questionable, if exposing students to such cruelty through visual aids is the right choice to represent the tragedy of the Holocaust. Of course, portraits of Lithuanians and other locals, who saved Jews, do not have any moral implications and are welcome as a highlight of common goodness, 
which still persisted during the Holocaust. But the main issue related with Holocaust visualization is an attempt by textbook authors to play with the feelings of students, because in the most cases Holocaust representation includes pictures of children - in ghettos, starving or begging for mercy (Bakonis, 2009, p. 100), or even photographs with such titles as „Even newborns had a yellow star on their nappies" (Bakonis, 2004, p. 89), which could not be taken lightly. It is important to note, that such sources with a strong emotional load should be used only to the necessary extent to supplement the presentation of the historical topic, it should not be the basis of it.

Next to the narrative and illustrations presented by the authors of the textbooks, it is very important to emphasize the educational part played by the selected excerpts both from the professional historical works and primary historical sources. However, in the analysed Lithuanian history textbooks there is a serious problem related with such fragments from primary historical sources - those sources are not identified, so it is difficult to evaluate the expedience and competence of presented materials. Primary sources chosen to supplement representation of ethnic minorities do not vary much in the textbooks; there are several main items, which are repeated over and over again in the textbooks prepared by different authors. One of the greatest attempts to integrate historical sources into the history education at school is the presentation of two controversial sources about the same event next to each other. And this kind of use of sources is mostly reflected in the representation of the Holocaust itself or Holocaust related issues - for instance, two academic opinions - by historians Liudas Truska and Algimantas Liekis - about the Lithuanian Jewish issue during the interwar period and its consequences related to the Holocaust (Bakonis, 2004). These kinds of controversies can encourage students to see into the main narrative presented in the textbook and raise their own questions, do not blindly follow just one opinion and understand that in the historical study not only facts, but interpretations play an important role. In the case of presenting historical sources one can look for a solution in trying to include excerpts from these sources into the overall story, or by making direct links to certain historical sources and their commentaries in the text. However, this kind of approach has a negative assessment in the academic world, as being artificial and only imitating "supposedly scientific textbook objectivity" (Merkinaitè, \& Radžvilas, 2011, p. 157). Authors of textbooks research made in the Institute of International Relations and Political Sciences (Vilnius University) are clearly against such double use of historical sources or encouragement of its "valueneutrality" (Merkinaitè, \& Radžvilas, 2011, p. 157). On the other hand, no other, more interesting or effective approach is being introduced. This perspective suggests not only a very questionable possibility for students and teachers to critically analyse information given in textbooks, but also encourages to subordinate overall history to one ideology. 


\section{CONCLUSIONS}

Although Holocaust education in Lithuania receives attention from both creators of educational programmes for schools and history textbook authors, it is still at the stage of primary development. However, it is not an exceptional situation - similar tendencies in Holocaust education can be seen in other neighbouring countries. In Lithuanian case the presentation of main historical data - numbers of victims, dates of certain events, names of certain people - is explicated and even illustrated by photographs. However, the level of interpretation of this information is quite low - it usually depends on the personal position of textbook author, and even if it could be seen as an inevitable fact of textbook preparation, the presented interpretation (with rare exceptions) lacks either basic historical knowledge, or tends to be nationalistically oriented towards the justification of the Lithuanian nation rather than explanation of Holocaust tragedy itself. However, despite the given critiques on the representation of the Holocaust in Lithuanian history education, we should notice, that the progress was made during the first two decades of Lithuanian independence - starting with the total absence of knowledge on the Holocaust topic in history textbooks, step by step authors have included major facts concerning the history of the Holocaust in Lithuania in their textbooks. With the promising new changes regarding the presentation of ethnic minorities and their history in Lithuania proposed in the newest educational program (2015-2017), there is a basis to believe, that in time representation of Holocaust history will become an integral part of Lithuanian history told based more on the facts and logic rather than emotion and guilt.

Table 1

Analysed history textbooks (1992-2012) for the $9^{\text {th }}-12^{\text {th }}$ grades

\begin{tabular}{|c|c|c|c|}
\hline No. & $\begin{array}{l}\text { Year of } \\
\text { publish- } \\
\text { ing }\end{array}$ & Authors & Textbook \\
\hline 1. & 1992 & J. Brazauskas & $\begin{array}{l}\text { Lietuvos istorija IX klasei. II dalis } \\
\text { [Lithuanian History for the } 9^{\text {th }} \text { grade. } \\
\text { II part]. Kaunas: Šviesa. }\end{array}$ \\
\hline 2. & 1993 & A. Gumuliauskas & $\begin{array}{l}\text { Lietuvos istorija nuo } 1915 \text { iki } 1953 \text { metu, } \\
\text { X klasei [Lithuanian History from } 1915 \\
\text { to } 1953,10^{\text {th }} \text { grade]. Kaunas: Šviesa. }\end{array}$ \\
\hline 3. & 1993 & $\begin{array}{l}\text { A. Kasperavičius, } \\
\text { R. Jokimaitis, } \\
\text { A. Jakubčionis }\end{array}$ & $\begin{array}{l}\text { Naujausiuju laiku istorija. 10. [History } \\
\text { of the } 20^{\text {th }} \text { century. 10] Kaunas: Šviesa. }\end{array}$ \\
\hline 4. & 1993 & $\begin{array}{l}\text { G. Jurkynienė, J. } \\
\text { Jurkynas, } \\
\text { A. Visockis }\end{array}$ & $\begin{array}{l}\text { Naujujų amžiu istorija. 9. [History of } \\
\text { the Modern times. 9] Kaunas: Šviesa. }\end{array}$ \\
\hline
\end{tabular}




\begin{tabular}{|c|c|c|c|}
\hline No. & $\begin{array}{l}\text { Year of } \\
\text { publish- } \\
\text { ing }\end{array}$ & Authors & Textbook \\
\hline 5. & 1996 & $\begin{array}{l}\text { A. Kasperavičius, } \\
\text { S. Jegelevičius, } \\
\text { S. Jurkevičius }\end{array}$ & $\begin{array}{l}\text { Naujuju amžiu istorija. 8. [History of } \\
\text { the Modern times. 8]. Kaunas: Šviesa. }\end{array}$ \\
\hline 6. & 1999 & $\begin{array}{l}\text { R. Jokimaitis, } \\
\text { A. Kasperavičius, } \\
\text { E. Manelis, } \\
\text { B. Stukienè. }\end{array}$ & $\begin{array}{l}\text { Pasaulio ir Lietuvos istorija, VI-XVIII } \\
\text { amžiai. 8. [History of the World and } \\
\text { Lithuania, 6-18 centuries. 8]. Vilnius: } \\
\text { Kronta. }\end{array}$ \\
\hline 7. & 2000 & B. Makauskas & $\begin{array}{l}\text { Lietuvos istorija [History of Lithuania]. } \\
\text { Kaunas: Šviesa. }\end{array}$ \\
\hline 8. & 2000 & $\begin{array}{l}\text { Z. Kiaupa, } \\
\text { A. Maesalu, } \\
\text { A. Pajir, G. Straube }\end{array}$ & $\begin{array}{l}\text { Baltijos šaliu istorija. [History of the } \\
\text { Baltic states]. Vilnius: Kronta. }\end{array}$ \\
\hline 9. & 2000 & $\begin{array}{l}\text { R. Kamuntavičius, } \\
\text { V. Kamuntavičienè, } \\
\text { R. Civinskas, } \\
\text { K. Antanaitis } \\
\end{array}$ & $\begin{array}{l}\text { Lietuvos istorija } 11-12 \text { klasems. [History } \\
\text { of Lithuania for the } 11-12^{\text {th }} \text { grades]. } \\
\text { Vilnius: Vaga. }\end{array}$ \\
\hline 10. & 2001 & $\begin{array}{l}\text { A. Kasperavičius, } \\
\text { R. Jokimaitis, } \\
\text { A. Sindaravičius, } \\
\text { J. Laurinaitis, } \\
\text { J. Brazauskas, } \\
\text { A. Čižauskienė, } \\
\text { B. Paulius } \\
\end{array}$ & $\begin{array}{l}\text { Naujausiuju laiku istorija. 10. [History } \\
\text { of the } 20^{\text {th }} \text { century.10]. Vilnius: Kronta. }\end{array}$ \\
\hline 11. & 2001 & $\begin{array}{l}\text { E. Bakonis, } \\
\text { J. Janušas } \\
\end{array}$ & $\begin{array}{l}\text { Lietuva ir pasaulis. 11. [Lithuania and } \\
\text { the World. 11]. Kaunas: Šviesa. }\end{array}$ \\
\hline 12. & 2001 & $\begin{array}{l}\text { A. Gečas, } \\
\text { J. Jurkynas, } \\
\text { G. Jurkynienė, } \\
\text { A. Visockis } \\
\end{array}$ & $\begin{array}{l}\text { Lietuva ir pasaulis. 12. [Lithuania and } \\
\text { the World. 12]. Kaunas: Šviesa. }\end{array}$ \\
\hline 13. & 2001 & $\begin{array}{l}\text { R. Kamuntavičius, } \\
\text { V. Kamuntavičienė }\end{array}$ & $\begin{array}{l}\text { Lietuvos istorija } 11 \text { klasei. [History of } \\
\text { Lithuania for the } 11^{\text {th }} \text { grade]. Vilnius: } \\
\text { Vaga. }\end{array}$ \\
\hline 14. & 2001 & $\begin{array}{l}\text { R. Civinskas, } \\
\text { K. Antanaitis }\end{array}$ & $\begin{array}{l}\text { Lietuvos istorija } 12 \text { klasei. [History of } \\
\text { Lithuania for the } 12^{\text {th }} \text { grade]. Vilnius: } \\
\text { Vaga. }\end{array}$ \\
\hline 15. & 2003 & $\begin{array}{l}\text { A. Galinis, } \\
\text { V. Gerulaitis, } \\
\text { S. Jurkevičius, } \\
\text { G. Sapožnikovas, } \\
\text { B. Šetkus }\end{array}$ & $\begin{array}{l}\text { Žemè ir laikas. Integruotas geografijos ir } \\
\text { istorijos vadovèlis. I dalis. 11-12 klasems. } \\
\text { [The Earth and the Time. Integrated } \\
\text { textbook for geography and history. } \\
\text { I part, 11-12 grades]. Vilnius: Briedis. }\end{array}$ \\
\hline
\end{tabular}




\begin{tabular}{|c|c|c|c|}
\hline No. & $\begin{array}{l}\text { Year of } \\
\text { publish- } \\
\text { ing }\end{array}$ & Authors & Textbook \\
\hline 16. & 2003 & $\begin{array}{l}\text { D. Česnavičius, } \\
\text { A. Galinis, } \\
\text { V. Gerulaitis, } \\
\text { S. Jurkevičius, } \\
\text { G. Sapožnikovas, } \\
\text { B. Šetkus }\end{array}$ & $\begin{array}{l}\text { Žemė ir laikas. Integruotas geografijos } \\
\text { ir istorijos vadovėlis. II dalis. 11-12 } \\
\text { klasems. [The Earth and the Time. } \\
\text { Integrated textbook for geography and } \\
\text { history. II part, 11-12 grades].Vilnius: } \\
\text { Briedis }\end{array}$ \\
\hline 17. & 2003 & $\begin{array}{l}\text { J. Jurkynas, } \\
\text { G. Jurkynienè, } \\
\text { A. Visockis } \\
\end{array}$ & $\begin{array}{l}\text { Lietuva pasaulyje, 9. [Lithuania in the } \\
\text { world, 9] Kaunas: Śviesa. }\end{array}$ \\
\hline 18. & 2004 & E. Bakonis & $\begin{array}{l}\text { Lietuva pasaulyje, 10. [Lithuania in the } \\
\text { world, 10] Kaunas: Šviesa. }\end{array}$ \\
\hline 19 . & 2004 & $\begin{array}{l}\text { S. Bitlieriūtè, } \\
\text { J. Litvinaitė }\end{array}$ & $\begin{array}{l}\text { Lietuva pasaulyje, 8. [Lithuania in the } \\
\text { world, 8] Kaunas: Šviesa. }\end{array}$ \\
\hline 20. & 2005 & $\begin{array}{l}\text { I. Kapleris, } \\
\text { A. Meištas, } \\
\text { K. Mickevičius, } \\
\text { L. Steponavičienè, } \\
\text { R. Ramanauskas, } \\
\text { Ž. Tamkutonytė- } \\
\text { Mikailienė }\end{array}$ & $\begin{array}{l}\text { Laikas. Istorijos vadovėlis, 8. I dalis. } \\
\text { [Time. History textbook, 8, I part]. } \\
\text { Vilnius: Briedis. }\end{array}$ \\
\hline 21. & 2005 & $\begin{array}{l}\text { I. Kapleris, } \\
\text { A. Meištas, } \\
\text { K. Mickevičius, } \\
\text { L. Steponavičienė, } \\
\text { R. Ramanauskas, } \\
\text { Ž. Tamkutonytè- } \\
\text { Mikailienè }\end{array}$ & $\begin{array}{l}\text { Laikas. Istorijos vadovelis, 8. II dalis. } \\
\text { [Time. History textbook, 8, II part]. } \\
\text { Vilnius: Briedis. }\end{array}$ \\
\hline 22. & 2006 & $\begin{array}{l}\text { I. Kapleris, } \\
\text { A. Meištas, } \\
\text { K. Mickevičius, } \\
\text { A. Laužikienė, } \\
\text { R. Ramanauskas, } \\
\text { Ž. Tamkutonytė- } \\
\text { Mikailienė }\end{array}$ & $\begin{array}{l}\text { Laikas, Istorijos vadovèlis, 9. I dalis } \\
\text { [Time, History textbook, 9. I part]. } \\
\text { Vilnius: Briedis. }\end{array}$ \\
\hline 23. & 2006 & $\begin{array}{l}\text { I. Kapleris, } \\
\text { A. Meištas, } \\
\text { K. Mickevičius, } \\
\text { A. Laužikienė, } \\
\text { R. Ramanauskas, } \\
\text { Ž. Tamkutonytė- } \\
\text { Mikailienė }\end{array}$ & $\begin{array}{l}\text { Laikas, Istorijos vadovelis, 9. II dalis } \\
\text { [Time, History textbook, 9. II part]. } \\
\text { Vilnius: Briedis. }\end{array}$ \\
\hline
\end{tabular}




\begin{tabular}{|c|c|c|c|}
\hline No. & $\begin{array}{l}\text { Year of } \\
\text { publish- } \\
\text { ing }\end{array}$ & Authors & Textbook \\
\hline 24. & 2007 & $\begin{array}{l}\text { I. Kapleris, } \\
\text { A. Meištas, } \\
\text { K. Mickevičius, } \\
\text { A. Laužikienė, } \\
\text { Ž. Tamkutonytė- } \\
\text { Mikailienė } \\
\end{array}$ & $\begin{array}{l}\text { Laikas, Istorijos vadovélis, 10. I dalis. } \\
\text { [Time. History textbook, 10, I part]. } \\
\text { Vilnius: Briedis. }\end{array}$ \\
\hline 25. & 2007 & $\begin{array}{l}\text { I. Kapleris, } \\
\text { A. Meištas, } \\
\text { K. Mickevičius, } \\
\text { A. Laužikienė, } \\
\text { Ž. Tamkutonytė- } \\
\text { Mikailienè } \\
\end{array}$ & $\begin{array}{l}\text { Laikas, Istorijos vadovélis, 10. II dalis. } \\
\text { [Time. History textbook, 10, II part]. } \\
\text { Vilnius: Briedis. }\end{array}$ \\
\hline 26. & 2008 & $\begin{array}{l}\text { G. Kaselis, } \\
\text { R. Morozovienė, } \\
\text { M. Tamošaitis }\end{array}$ & $\begin{array}{l}\text { Istorijos vadovélis, 12. I dalis. [History } \\
\text { textbook, 12. I part]. Vilnius: Baltos } \\
\text { lankos. }\end{array}$ \\
\hline 27. & 2008 & $\begin{array}{l}\text { G. Kaselis, } \\
\text { R. Kraujelis, } \\
\text { S. Lukšys, } \\
\text { A. Streikus, } \\
\text { M. Tamošaitis } \\
\end{array}$ & $\begin{array}{l}\text { Istorijos vadovelis, 12. II dalis. [History } \\
\text { textbook, 12. II part]. Vilnius: Baltos } \\
\text { lankos. }\end{array}$ \\
\hline 28. & 2008 & $\begin{array}{l}\text { J. Litvinaitè, } \\
\text { S. Bitlieriūtė }\end{array}$ & $\begin{array}{l}\text { Tévynejje ir pasaulyje, } 8 . \text { [In the } \\
\text { homeland and in the world, } 8 \text { ]. } \\
\text { Kaunas: Šviesa. }\end{array}$ \\
\hline 29. & 2009 & $\begin{array}{l}\text { A. Galinis, } \\
\text { S. Jurkevičius, } \\
\text { K. Petrauskis }\end{array}$ & $\begin{array}{l}\text { Naujuju amžiu istorija, 9. [History of } \\
\text { the Modern times, 9]. Vilnius: Kronta. }\end{array}$ \\
\hline 30. & 2009 & E. Bakonis & $\begin{array}{l}\text { Tévynejje ir pasaulyje, 10. [In the } \\
\text { homeland and in the world, 10]. } \\
\text { Kaunas: Šviesa. }\end{array}$ \\
\hline 31. & 2009 & $\begin{array}{l}\text { J. Jurkynas, } \\
\text { G. Jurkynienė, } \\
\text { A. Visockis }\end{array}$ & $\begin{array}{l}\text { Tèvynejje ir pasaulyje, 9. [In the } \\
\text { homeland and in the world, 9]. } \\
\text { Kaunas: Šviesa. }\end{array}$ \\
\hline 32. & 2010 & M. Tamošaitis & $\begin{array}{l}\text { Istorijos vadovelis, 10. I dalis. [History } \\
\text { textbook, 10, I part]. Vilnius: Baltos } \\
\text { lankos. }\end{array}$ \\
\hline 33. & 2010 & $\begin{array}{l}\text { R. Kraujelis, } \\
\text { A. Streikus, } \\
\text { M. Tamošaitis }\end{array}$ & $\begin{array}{l}\text { Istorijos vadovelis, 10. II dalis. [History } \\
\text { textbook, 10, II part]. Vilnius: Baltos } \\
\text { lankos. }\end{array}$ \\
\hline 34. & 2010 & $\begin{array}{l}\text { S. Lukšys, } \\
\text { M. Ščavinskas, } \\
\text { M. Vitkūnas }\end{array}$ & $\begin{array}{l}\text { Istorijos vadovelis, 8. I dalis. [History } \\
\text { textbook, 8, I part]. Vilnius: Baltos } \\
\text { lankos. }\end{array}$ \\
\hline
\end{tabular}




\begin{tabular}{|c|c|c|c|}
\hline No. & $\begin{array}{l}\text { Year of } \\
\text { publish- } \\
\text { ing }\end{array}$ & Authors & Textbook \\
\hline 35. & 2010 & $\begin{array}{l}\text { S. Lukšys, } \\
\text { M. Ščavinskas, } \\
\text { M. Vitkūnas } \\
\end{array}$ & $\begin{array}{l}\text { Istorijos vadovélis, 8. II dalis. [History } \\
\text { textbook, 8, II part]. Vilnius: Baltos } \\
\text { lankos. }\end{array}$ \\
\hline 36. & 2010 & $\begin{array}{l}\text { R. Butvilaitė, } \\
\text { D. Karvelis, } \\
\text { N. Kostinienė, } \\
\text { S. Lukšys, } \\
\text { S. Pivoras, } \\
\text { M. Tamošaitis. }\end{array}$ & $\begin{array}{l}\text { Istorijos vadoveilis, 9. I dalis. [History } \\
\text { textbook, 9, I part]. Vilnius: Baltos } \\
\text { lankos. }\end{array}$ \\
\hline 37. & 2010 & $\begin{array}{l}\text { S. Lukšys, } \\
\text { S. Pivoras, } \\
\text { M. Tamošaitis } \\
\end{array}$ & $\begin{array}{l}\text { Istorijos vadovélis, 9. II dalis. [History } \\
\text { textbook, 9, II part]. Vilnius: Baltos } \\
\text { lankos. }\end{array}$ \\
\hline 38. & 2010 & $\begin{array}{l}\text { I. Kapleris, } \\
\text { R. Laužikas, } \\
\text { A. Meištas, } \\
\text { K. Mickevičius, } \\
\text { M. Žolynas. }\end{array}$ & $\begin{array}{l}\text { Laikas, Istorijos vadovélis, 11. I dalis. } \\
\text { [Time. History textbook, 11, I part]. } \\
\text { Vilnius: Briedis. }\end{array}$ \\
\hline 39. & 2010 & $\begin{array}{l}\text { I. Kapleris, } \\
\text { R. Laužikas, } \\
\text { A. Meištas, } \\
\text { K. Mickevičius, } \\
\text { M. Žolynas. } \\
\end{array}$ & $\begin{array}{l}\text { Laikas, Istorijos vadovèlis, 11. II dalis. } \\
\text { [Time. History textbook, 11, II part]. } \\
\text { Vilnius: Briedis. }\end{array}$ \\
\hline 40. & 2012 & $\begin{array}{l}\text { S. Bitlieriūtè, } \\
\text { A. Jakubčionis }\end{array}$ & $\begin{array}{l}\text { Pilietiškumo pagrindai ir laisvés kovu } \\
\text { istorija: vadovélis } 9-10 \text { klasei. [Basics of } \\
\text { citizenship and history of freedom } \\
\text { fighters: textbook for } 9-10^{\text {th }} \text { graders]. } \\
\text { Kaunas: Šviesa. }\end{array}$ \\
\hline
\end{tabular}

\section{REFERENCES}

1. A list of textbooks approved for the 2011-2012 school years. (2012). Retrieved January 13, 2017 from http://www.sac.smm.lt/mokymosi-istekliai/vadoveliai/bendrojo-ugdymo-dalykuvadoveliai/

2. Bakonis, E. (2004). Lietuva pasaulyje, 10 [Lithuania in the world, 10]. Kaunas: Šviesa.

3. Bakonis, E. (2009). Téryneje ir pasaulyje 10 [In the homeland and all over the world, 10]. Kaunas: Šviesa.

4. Bakonis, E., Jokimaitis, R., \& Manelis, E. (Eds.). (1997). Bendrojo lavinimo mokyklos programos: istorija V-XII klasei [Programs for general education: history for the 5th-12th grades]. Vilnius: Leidybos centras.

5. Bitlieriūtè, S., \& Litvinaitè, J. (2008). Téryneeje ir pasaulyje, 8 [In the homeland and all over the world, 8]. Kaunas: Šviesa.

6. Butvilaitė, R., Karvelis D., Kostinienė, N., Lukšys, S., Pivoras, S., \& Tamošaitis, M. (2010). Istorijos vadovelis I dalis, 9 [History textbook, I part, 9]. Vilnius: Baltos lankos. 
7. Dietsch, J. (2012). Textbooks and the Holocaust in Independent Ukraine. An Uneasy Past. European Education, vol. 44(3).

8. Gečas, A., Jurkynas, J., Jurkynienè, G., \& Visockis, A. (2001). Lietuva ir pasaulis, 12 [Lithuania and the World, 12]. Kaunas: Šviesa.

9. General programs for primary and middle-school education. (2012). Retrieved January 8, 2017 from http://www.smm.lt/ugdymas/bendrasis/ugd_programos.htm.

10. Hungary anti-Semitism: MP condemned over "list of Jews". (2012). Retrieved January 16, 2017 from http://www.bbc.co.uk/news/world-europe-20510648

11. Anti-Semitism in Hungary: Marton's list. (2012). Retrieved January 16, 2017 from http:/ / www.economist.com/blogs/easternapproaches/2012/11/anti-semitism-hungary

12. Jakubčionis, A., \& Kaubrys, S. (2006). Lietuvos istorija 1918-1990 m.: programa [Lithuanian History 1918-1990: curriculum]. Vilnius: Vilniaus universiteto leidykla.

13. Kapleris, I., Meištas, A., Mickevičius, K., Laužikienè, A., \& Tamkutonytè-Mikailienè, Ž. (2007a). Laikas: istorijos vadovélis, 10. II dalis [Time: history textbook, 10, II part]. Vilnius: Briedis.

14. Kapleris, I., Meištas, A., Mickevičius, K., Laužikienė, A., \& Tamkutonytè-Mikailienė, Ž. (2007b). Laikas: istorijos vadovelis, 10, I dalis. [The Time: history textbook, 10, I part.]. Vilnius: Briedis.

15. Kasperavičius, A., Jokimaitis, R., Sindaravičius, A., Laurinaitis, J., Brazauskas, J., Čižauskienè, A., \& Paulius, B. (2001). Naujausiuju laiku istorija, 10 [History of the $20^{\text {th }}$ century]. Vilnius: Kronta.

16. Kovacs, M. (2000). Treatment of Jewish Themes in Hungarian Schools. Retrieved January 13, 2017 from http://www.ajc.org/atf/cf/\%7B42d75369-d582-4380-8395-d25925b85eaf\%7D/ treatment_jewish_themes_hungarian_schools.pdf.

17. Krichevsky, L. (2001). Treatment of Jewish Themes in Russian Schools. Retrieved January 13, 2017 from http:/ / www.ajc.org/atf/cf/ \%7B42d75369-d582-4380-8395-d25925b85eaf\%7D/ treatment_jewish_themes_russian_schools.pdf.

18. Krieg, L. J. (2015). “Who Wants to Be Sad Over and Over Again?" Emotion Ideologies in Contemporary German Education about the Holocaust. Journal of Educational Media, Memory, and Society, Volume 7, Issue 2, Autumn 2015, 110-128.

19. Laužikas, R. (2008). Kelias: istorijos vadovelis $5 \mathrm{kl}$. [The Road: history textbook for the 5th grade]. Vilnius: Briedis.

20. Sirutavičius, V., Staliūnas, D., \& Šiaučiūnaitè-Verbickienè J. (Eds.). (2012). Lietuvos žydai. Istorine studija [Lithuanian Jews. Historical study]. Vilnius: Baltos lankos.

21. Lindquist, D. H. (2006). Guidelines for Teaching the Holocaust: Avoiding Common Pedagogical Errors. The Social studies, September/October 2006.

22. Merkinaitè, S., Radžvilas, V. (2011). Istorijos mokymas mokyklose kaip valstybinės istorijos politikos problema [History education in schools as an issue of history politics of the State]. In: V. Radžvilas (Ed.). Istorijos subjektas kaip istorijos politikos problema. Vilnius: Vilniaus universitetas.

23. Nasson L. (2013). The Holocaust - modes of remembrance and education. Jewish Affairs. Cape Town.

24. Pawlat, L. (2000). Treatment of Jewish Themes in Czech Schools. Retrieved January 13, 2017 from http://www.ajc.org/atf/cf/\%7B42D75369-D582-4380-8395-D25925B85EAF\%7D/ Treatment_Jewish_Themes_Czech_Schools.pdf.

25. Salner P., \& Salnerova E. (1999). Treatment of Jewish Themes in Slovak Schools. Retrieved January 13, 2017 from http:/ / www.ajc.org/atf/cf/\%7B42D75369-D582-4380-8395-D25925B85EAF\%7D/Treatment_Jewish_Themes_Slovak_Schools.pdf.

26. Šiaučiūnaitè-Verbickienè, J. (2009). Žydiškas Vilnius: kaip jị suprantame? [Jewish Vilnius: how do we understand it?]. In: A. Bumblauskas, G. Potašenko, \& Š. Liekis (Eds.), Naujasis Vilniaus perskaitymas. Vilnius: Vilniaus universiteto leidykla.

27. Skirius, J. (2009). Istorijos mokymas vidurinèje mokykloje - naujas požiūris ir kitokio pobūdžio vadovèliai [History teaching in middle school - new attitude and different textbooks]. Istorija, 76, 62-67.

28. Socialinis ugdymas: istorija, geografija, integruotas istorijos ir geografijos kursas, teisé, religijotyra, filosofija, ekonomika ir verslumas, psichologija [Social education: history, geography, integra- 
ted course of history and geography, law, religion, philosophy, economics, psychology]. In: Vidurinio ugdymo bendrosios programos. Approved: $21^{\text {st }}$ of February, 2011. Retrieved January 15, 2017 from http://www.upc.smm.lt/suzinokime/bp/2011/.

29. Tamošaitis, M. (2010). Istorijos vadovélis, I dalis, 10 [History textbook, I part, 10]. Vilnius: Baltos lankos.

30. Węrzynek, H. (1998). Treatment of Jewish Themes in Polish Schools. Retrieved January 13, 2017 from http://www.ajc.org/atf/cf/\%7B42D75369-D582-4380-8395-D25925B85EAF\% 7D/Treatment_Jewish_Themes_Polish_Schools.pdf. 